\title{
Laboratory Diagnosis of Chlamydial and Viral Ocular Infections
}

\author{
R M WOODLAND
}

London

Conjunctivitis and keratitis account for the majority of cases of ocular morbidity seen by family doctors, general practitioners, health centres and local ophthalmic clinics; up to $70 \%$ of cases in developed countries and possibly as high as $90 \%$ in developing countries. ${ }^{1}$ The common causes of conjunctivitis and keratitis are bacterial, chlamydial, viral and parasitic infections, protein and vitamin A deficiencies, and allergies. The identification of causative microorganisms is essential for the correct management of ocular infections. ${ }^{2}$ However, clinical diagnosis is not reliable and in many cases the correct diagnosis can only be achieved with the aid of laboratory tests. ${ }^{3}$ In the absence of such tests many cases of ocular infections may be incorrectly diagnosed. In one study in London, only $49 \%$ of cases from whom either Chlamydia trachomatis, adenovirus or herpes simplex virus (HSV) were isolated had been correctly identified by the clinician. ${ }^{4}$

The Section of Virology of the Institute of Ophthalmology, has been involved in the development and improvement of laboratory diagnostic tests for chlamydial and viral ocular infections since its formation in 1964. This paper discusses the diagnostic techniques which have been developed for these infections since that time, with particular emphasis on the contributions made by the Institute of Ophthalmology.

\section{The Nature of Laboratory Tests}

Diagnostic techniques can be conveniently divided into four categories:

(a) Cytological tests. In these tests, the cause of the disease is inferred from the types of inflammatory cells present on the con- junctiva. The result can only be presumptive but the test is rapid and inexpensive.

(b) Direct detection tests. In these tests specimens from the patient are tested directly either for the presence of relevant microorganisms or of antigens specific to that microorganism. The microorganisms detected do not need to be viable but they may be present only in small quantities so the sensitivity of the test must be high.

(c) Culture or isolation tests. In this case the specimen is cultured to grow the organism. Small quantities can usually be detected as the organisms multiply during the test. It is important that the specimens collected contain sufficient epithelial cells and they must be transported to the laboratory in a manner designed to preserve the viability of the organisms.

(d) Serological tests. In these tests, patients' sera or local secretions are tested for antibodies to the microorganism. The presence of specific antibodies indicates a patient's exposure to the particular infection in the past or present. The presence of specific IgM antibodies or a high titre of IgG antibodies in the blood is suggestive of the present infection. In some cases, the presence of antibodies in local secretions has been shown to correlate well with active disease. The absence of antibodies to a particular microorganism argues against it being the cause of an infection unless the specimen has been taken so soon after onset that there has been no time for antibody production. A definitive diagnosis can be obtained if a second sample is tested at least 
two weeks after the first and seroconversion or a four-fold rise in antibody titre is detected.

\section{Cytological Tests}

The conjunctival cytology of ocular infections was described by Thygeson. ${ }^{5}$ During the acute phase of disease, between about one and six weeks after onset, the inflammatory cells present in bacterial infections were predominantly polymorphonuclear leucocytes while in viral infections they were mainly mononuclear. Chlamydial infections tended to have mixed polymorphonuclear and mononuclear cells while the presence of large numbers of eosinophils indicated an allergic conjunctivitis. These cytological patterns have been used as the basis for a simple, rapid, diagnostic test to supplement clinical findings and allow treatment to be started before the results of more specific tests are available. Cells are collected from the anaesthetised conjunctiva by scraping the surface with a metal spatula. The collected material is spread on a microscope slide and stained with a cytological stain such as Giemsa before microscopic examination. The results must however be interpreted with care as, in all infections, polymorphonuclear leucocytes predominate during the very eary stages and mononuclear cells predominate in chronic infections. The presence of polymorphonuclear leucocytes in scrapings has also been used as a guide for the likelihood of finding chlamydial inclusions in scrapings from trachomatous patients. ${ }^{6}$

Conjunctival scraping is extremely traumatic. To remedy this, we have developed a plastic impression spatula to provide a relatively nontraumatic method for collecting inflammatory cells from non-anaesthetised eyes. ${ }^{7}$ The inflammatory cells collected by these impression spatulas correlated closely to those collected by scraping, but the numbers of epithelial cells collected tended to be fewer.

\section{Direct Detection Tests}

Chlamydia trachomatis was first detected in Giemsa stained conjunctival smears taken from the eye of an orang-outang which had been experimentally inoculated with material taken from the eyes of patients suffering from trachoma, and were later seen in conjunctival smears from patients with trachoma in Java. ${ }^{8}$
Similar inclusions were detected in babies suffering from ophthalmia neonatorum and from adults suffering from inclusion conjunctivitis or punctate keratoconjunctivitis. ${ }^{9}$ Prior to the advent of more sensitive culture methods, this technique was used as a diagnostic test for ocular chlamydial infections. In most cases, scrapings were only taken from the upper tarsus, but it was found that examination of smears from other areas of the conjunctiva as well resulted in a $30 \%$ improvement in sensitivity for chlamydial ocular infections in London and a $180 \%$ improvement for trachoma. ${ }^{10}$

In recent years, more sensitive and specific immunochemical stains have been developed and direct detection methods have seen a new lease of life for diagnosing chlamydial eye infections. In a study in London, immunofluorescent staining was significantly more sensitive than Giemsa stain for detecting chlamydial inclusions in conjunctival and genital scrapings. ${ }^{10}$ Immunofluorescent staining of conjunctival smears proved to be almost as sensitive as cell culture for the diagnosis of hyperendemic trachoma when specimens were collected from all areas of the conjunctiva. "In the same study, the traditional method of collecting scrapings from the upper tarsus alone resulted in a significant number of trachoma cases being missed.

Immunoperoxidase staining has been used as an alternative to immunofluorescent staining for detecting chlamydial inclusions in conjunctival scrapings. ${ }^{12}$ The sensitivities of the two methods were similar for detecting Chlamydia psittaci inclusions in smears from infected cats. In the immunoperoxidase stained smears, inclusions showed less contrast against the background compared with immunofluorescent stained inclusions, but the immunoperoxidase method had the advantage that permanent preparations were produced and normal light field microscopy could be used for the examination.

The immunochemical methods described above all used polyclonal antisera and depended on the detection of intracellular inclusion bodies in conjunctival smears. The development of antichlamydial monoclonal antibodies ${ }^{13}$ and their use in immunochemical staining now allows chlamydial elementary bodies (EBs) to be identified reliably in such specimens. ${ }^{14}$ The reagents for monoclonal antibody based direct 
immunofluorescence tests are now available commercially. The test is extremely rapid and a result can be obtained in less than one hour. Generally, ten or more EBs are required for a positive result but some workers have reported positivity on seeing a single EB. ${ }^{15}$ Most testing of this method has been done using genital specimens, for which sensitivities ranging between $70 \%$ and $100 \%$ compared to cell culture isolation have been reported, depending on the source of the specimens and the minimum number of EBs required for positivity. ${ }^{15,16}$ Only a few studies have been performed using ocular specimens. ${ }^{17,18,19}$ These have suggested a similar sensitivity to genital specimens, but the numbers of patients have been small and more comprehensive studies are needed. Studies in our laboratories have suggested that this method is as sensitive as cell culture for specimens from patients with moderate to severe conjunctivitis (unpublished data).

The speed and simplicity of the direct immunofluorescence test suggests that this test could be applied in the clinic to obtain results while the patient waits and so appropriate treatment could be started immediately. However, cross reactions with other bacteria have been reported, ${ }^{20}$ some workers have reported problems with false positivity, especially when a low number of EBs are accepted for a positive result, and an experienced microscopist is required for reliable results. ${ }^{16}$ This makes the test impractical for many clinics and the need to send specimens to specialist laboratories cancels out the speed advantage compared to other methods.

Immunochemical methods have also been developed to detect other viruses in clinical specimens. Both immunofluorescence and immunoperoxidase staining methods have been used to diagnose HSV in corneal scrapings. . $^{21,22}$ Fluorescein labelled monoclonal antibodies to HSV are available commercially and these have been used to detect virus infected cells in smears from skin vesicles. ${ }^{23}$ Immunofluorescence has also been used to diagnose adenovirus ocular infections. ${ }^{24}$

A cytospin diagnostic test for chlamydial, HSV and adenoviral ocular infections has been developed at the Institute of Ophthalmology. ${ }^{1}$ In this test, a cytocentrifuge is used to deposit cells collected from the conjunctiva onto a micro- scope slide. These cells are then stained with a mixture of antibodies conjugated with different fluorochromes to detect cells infected with chlamydiae or viruses in a single sample. This technique has been found to be at least as sensitive as cell culture isolation for all three infections.

In recent years, enzyme immuno-assays have been developed to detect microbial antigens in clinical specimens. These tests use enzymelabelled antibodies and substrate to produce a colour which can be read spectrophotometrically. They can therefore be automated and are better suited to testing large numbers of specimens than those which require microscopy. Reagents for the detection of chlamydiae are available commercially. Most testing has been carried out on genital specimens, for which the sensitivity is similar to direct immunofluorescence, ${ }^{25}$ but preliminary results on ocular specimens from patients with moderate to severe conjunctivitis suggest that the sensitivity is similar to cell culture isolation ${ }^{26}$ and to direct immunofluorescence (unpublished observation). However, false positive results have been encountered in some specimens and extensive testing is therefore needed before enzyme immuno-assays can be reliably used for diagnosis. They are probably best employed at present in laboratories which are able to confirm positive results by another test.

Immuno-assays for the diagnosis of adenovirus and HSV infection have been developed ${ }^{27,28}$ but have yet to be applied satisfactorily to ocular specimens.

\section{Isolation Tests}

Chlamydia trachomatis was first isolated in 1957 by T'ang and colleagues who inoculated conjunctival material from a patient with trachoma into the yolk sacs of 6 to 8 day embryonate eggs. ${ }^{29}$ This was later confirmed by Collier and Sowa. ${ }^{30}$ In 1959 Jones and colleagues reported the isolation in eggs of chlamydiae from the eyes of a baby with ophthalmia neonatorum and from the cervix of the mother of a baby with ophthalmia neonatorum at Moorfields Eye Hospital. ${ }^{31}$ This culture method was subsequently used as a diagnostic test but several blind passages were often needed to obtain an isolation. The long time needed to obtain results, the high costs, and the risk of cross infection of 
eggs $^{32}$ limited the usefulness of this method for diagnostic purposes.

Early attempts to establish $C$. trachomatis infections in cell cultures were generally less sensitive than eggs and could often only be achieved after the isolate had been passaged several times through eggs. ${ }^{33}$ The first practical cell culture diagnostic technique for chlamydial infections was achieved by the centrifuge assisted inoculation of irradiated McCoy cells. ${ }^{34,35}$ This technique was shown to be three to four times more sensitive than yolk sac isolation for primary isolation of chlamydiae..$^{36}$ The technique initially required up to three passages to establish a diagnosis but this was later simplified to require only one passage by using a higher temperature during centrifugation $\left(35-38^{\circ} \mathrm{C}\right)$, a higher centrifugal force $(2,700 \mathrm{~g})$, improved transportation to the laboratory in liquid nitrogen, and the inclusion of $3 \%$ fetal bovine serum in the transport medium. ${ }^{37,38}$ The sensitivity was further improved by using conjunctival swabbing to collect infected material from the conjunctiva instead of scraping as had been used previously. ${ }^{39}$ Using these techniques, an isolation rate as high as $79 \%$ was achieved from ocular specimens. ${ }^{38}$ Increasing the centrifugal forces to $15,000 \mathrm{~g}$ significantly increased the number of inclusions and also the rate of positivity for clinical specimens with a low titre of infectivity. ${ }^{40}$

The routine use of irradiated McCoy cells for diagnosis depended on the ready availability of a convenient source of ionising irradiation. To overcome this shortcoming, various other methods for treating cell cultures to increase

Table I Types of cells and treatments used for the diagnostic isolation of Chlamydia trachomatis

\begin{tabular}{ll}
\hline Cell type & Treatment \\
\hline McCoy & Irradiation $^{34.35}$ \\
HeLa 229 & diethylaminoethyl-dextran $^{85,86}$ \\
McCoy & 5-iodo-2' -deoxyuridine $^{87}$ \\
McCoy & cytochalasin B $^{88}$ \\
BHK-21 & \\
McCoy & cycloheximide $^{90}$ \\
McCoy & cortisol $^{91}$ \\
McCoy & emetine $^{92}$ \\
Green monkey kidney & \\
(BGM) & cycloheximide $^{93}$ \\
McCoy & Mitomycin-C $^{42}$ \\
\hline
\end{tabular}

their susceptibility to chlamydial infection have been developed (Table I). These methods have made chlamydial isolation practical for laboratories that do not have a radiation source. Studies which have compared the sensitivities of these various methods have failed to show a major advantage of one method compared to the others. ${ }^{41}$ In our laboratory we have recently developed a method of pre-treating McCoy cells with mitomycin-C to produce large cells similar in appearance and sensitivity to irradiated McCoy cells. ${ }^{42}$ The inclusions produced are larger and easier to detect than those produced in cycloheximide treated McCoy cells. The mitomycin-C treated cell monolayers remained stable and could be used for up to six days after preparation, making it possible to prepare cells once each week to use for the rest of the week.

Various staining methods have been used to visualise chlamydial inclusions in infected cell cultures. ${ }^{41}$ Both Giemsa and iodine staining have been commonly used to detect $C$. trachomatis inclusions in infected cell cultures. Iodine stains the glycogen matrix of the $C$. trachomatis inclusion, but this is only detectable in mature inclusions. Giemsa stains the chlamydial elementary and reticulate bodies in the inclusion and, when examined by dark field microscopy, mature inclusions "autofluoresce" a bright yellow-green colour. However, $C$. psittaci inclusions do not "autofluoresce" when stained by this method, and do not stain with iodine as they lack glycogen. To overcome this problem, we have developed a rapid stain using methyl green and neutral red dyes which is highly sensitive for $C$. psittaci inclusions and can also detect $C$. trachomatis inclusions. ${ }^{43}$

Immunochemical staining methods have also been widely adopted for staining chlamydial inclusions in cell cultures. Immunofluorescence and immunoperoxidase staining were found to be as sensitive as Giemsa staining for $C$. trachomatis inclusions and far superior to Giemsa for C. psittaci inclusions. ${ }^{2}$ Immunochemical staining has the additional advantage that inclusions can be detected as early as 18 hours after inoculation, thereby reducing the time needed to perform the test. ${ }^{12,44}$

Isolation techniques for adenovirus and HSV have been developed alongside those for chlamydiae. The standard cell culture test depended for a positive result on the develop- 
ment of cytopathic effects during the three to four weeks after inoculation. Using this technique, human embryo kidney cells were found to be more sensitive than HeLa cells or W138 cells for the primary isolation of adenovirus from the eye. ${ }^{45}$ Isolation was found to be more sensitive than diagnosis by a four-fold rise in antibody titre determined by a complement fixation test. ${ }^{46}$ The highest isolation rate was $66 \%$ for specimens collected during the first week, falling to $25 \%$ during the second week and $12 \%$ during the third and fourth weeks after the onset of disease.

Rapid culture tests for the diagnosis of both adenovirus and HSV eye infections have been developed in our laboratories. ${ }^{47.48}$ In both of these tests, clinical specimens were inoculated onto HEp2 cell monolayers growing on glass coverslips in flat bottomed tubes. After 48 hours the cells were fixed and stained by immunofluorescence using specific antisera to detect virus infected cells. High speed centrifugation $\left(15,000 \mathrm{~g}\right.$ at $35^{\circ} \mathrm{C}$ for 1 hour $)$ significantly increased the isolation rate of $\mathrm{HSV}^{49}$ but had no effect on the isolation of adenovirus. ${ }^{47}$ The sensitivity of the rapid culture tests for adenovirus was similar to the conventional test, while the HSV rapid culture test was $21 \%$ more sensitive than the conventional test. Rapid tests for these two viruses can now be performed at the same time on a single cell culture monolayer. The infected cells are stained by a double immunofluorescence staining technique in which both fluorescein and rhodamine labelled antibodies are used. ${ }^{50}$

\section{Serological Tests}

Staff of the Institute of Ophthalmology have been extensively involved in the development of practical and reliable serodiagnostic tests for ocular infections, particularly chlamydial infections.

The first such test for chlamydiae was the complement fixation test using an antigen prepared by boiling yolk-sac cultured organisms. This had been used with some success for the serodiagnosis of systemic chlamydial infections such as psittacosis and lymphogranuloma venereum $^{51}$ but its sensitivity was too low for the test to be useful for localised infections, such as eye and genital tract infections. ${ }^{52,53}$ In addition the complement fixation test only detected antibody to the chlamydial group antigens and it was therefore unable to distinguish between the different chlamydial serotypes. $^{54}$

In 1970, an indirect micro-immunofluorescence typing test was described. ${ }^{55}$ This has since been used to differentiate the various serotypes of $C$. trachomatis. ${ }^{56.57 .58}$ These serotypes have been divided into three major epidemiological and/or clinical groupings. ${ }^{59}$ Serotypes A to $\mathrm{C}$ are mainly associated with trachoma of eye to eye transmission, while types $\mathrm{D}$ to $\mathrm{K}$ are generally associated with genital to genital and secondary eye infections. Three serotypes (L1, L2 and L3) are generally associated with lymphogranuloma venereum.

The micro-immunofluorescence technique has been adapted to provide the basis of a serodiagnostic test for chlamydia-specific antibody in patients. ${ }^{60}$ Dilutions of patients' sera are tested in indirect immunofluorescent stainıng of dots of chlamydial antigens placed on a microscope slide. The test is more sensitive than the complement fixation test and the use of all serotypes of $C$. trachomatis in the test allows the detection of type specific antibody in serum. Sera from patients with trachoma could be easily distinguished from those with ocular or genital infections in London and the USA. ${ }^{60}$ Sera from patients with LGV tended to have higher titres but were generally more cross-reactive with other chlamydiae. To facilitate these tests, techniques have been developed using cellulose sponges for the collection of blood by finger prick and for the collection of tears. ${ }^{61}$

The preparation of antigens and testing of sera against all 15 serotypes of $C$. trachomatis is time consuming and laborious. The test has therefore been further refined by using three pools of antigen serotypes representing the three major epidemiological and/or clinical groups of $C$. trachomatis. A fourth pool representing some of the more commonly encountered $C$. psittaci infections was also included in the test. ${ }^{62} \mathrm{By}$ this method, antibodies could be detected in the sera of infected patients and thus an indication as to the clinical and epidemiological type of chlamydial infection obtained. There was a slight loss in sensitivity when compared to individual antigens but this was more than compensated for by the reduction in cost and the large increase in the number of sera which could be examined. 
Single antigen immunofluorescence tests have been developed for the serodiagnosis of chlamydial infections. ${ }^{63,64,65}$ Radioimmunoassays and enzyme linked immuno-assays have also been developed. ${ }^{66.67,68}$ These are of similar sensitivity to the micro-immunofluorescence test and can be automated. However, all of these tests which use a single antigen detect group specific antibodies. Thus they are not able to distinguish infections caused by $C$. trachomatis $\mathrm{A}$ to $\mathrm{C}$ (trachoma), D to K (genital infection), LGV, $C$. psittaci, or the recently described TWAR group of chlamydiae. ${ }^{69,70}$ This is especially important considering the high prevalence of antibodies to the TWAR chlamydiae, which primarily cause respiratory infections. In London, antibodies to Chlamydia IOL-207, which is serologically identical to the TWAR chlamydiae, were detected in $14 \%$ of women and $24 \%$ of men blood donors. ${ }^{71}$ The prevalence of antibodies to C. IOL-207 in unselected patients attending an eye clinic in the United Kingdom has increased from about $12 \%$ in 1979 to about $28 \%$ in $1984 .^{72}$ These antibodies showed a significant degree of cross-reactivity with $C$. trachomatis and it is likely that many of these sera would have given positive results in tests using a single C. trachomatis antigen. ${ }^{71,72}$ In a comparative study using sera from blood donors and men with urethritis, antibodies could be detected in $70 \%$ using the micro-immunofluorescence test and in $76 \%$ using a single antigen inclusion immunofluorescence test. However, in almost half of the sero-positive specimens the antibodies were specific to $C$. IOL-207, ${ }^{73}$ indicating that reliance on genus-specific serology tests would lead to false diagnosis and a considerable over-estimation of the prevalence of $C$. trachomatis infections.

The problems of the cross-reactivity of sera, together with the persistence of circulating antibodies from previous infections makes interpretation of results from a single serological test difficult. If a second serum sample can be collected and seroconversion or a four-fold rise in titre demonstrated, then a firm diagnosis can be made, but this can rarely be achieved. To try to obtain a valid result from a single serological specimen, the occurrence of the various classes of antibodies in both blood and tears has been investigated. These include IgG and IgM antibodies in blood and IgG and IgA antibodies in tears. The results indicate that a low titre of $\mathrm{IgG}$ antichlamydial antibodies in the blood is likely to be derived from a previous infection. Higher titres however are more likely to be associated with a current infection. In a study in London, over $80 \%$ of patients who had type-specific antichlamydial IgG at a level of 1:32 or higher had active ocular infection. ${ }^{61}$ In hyperendemic trachoma areas, the geometric mean titre of serum antibody in culture positive patients was generally between 1:64 and 1:128. Similar titres were also seen in patients with trachoma from whom $C$. trachomatis could not be isolated. ${ }^{74}$ The presence of high levels of IgG antibodies in the blood can therefore be regarded as a guide to the diagnosis.

IgM antibodies are generally produced only in the early stages of a disease and their presence indicates an active or recent infection. The presence of antichlamydial $\operatorname{IgM}$ antibodies therefore correlates highly with active disease. In one study, $88 \%$ of patients with IgM had active chlamydial ophthalmia. Thirty three percent of those with chlamydial ophthalmia had IgM antibodies. ${ }^{61}$ However, IgM is rarely found in hyperendemic trachoma because most patients may have a chronic infection or have been exposed repeatedly to $C$. trachomatis infection. ${ }^{74}$

It has been suggested recently that specific antichlamydial $\operatorname{IgA}$ antibodies in the serum could possibly be used as markers of active chlamydial infections. ${ }^{75}$ Raised titres of these antibodies correlated well with chlamydial isolation from patients with non-gonococcal urethritis and were found in significantly more cases with epididymitis and salpingitis than in control groups.

The presence of specific antichlamydial IgG and $\operatorname{IgA}$ in tears has been found to correlate closely to active disease. Thus, $96 \%$ of patients with tear IgG antibodies and $100 \%$ of those with tear IgA antibodies had active paratrachoma. ${ }^{61}$ Antichlamydial IgG has been found in the tear fluids of $95 \%$ and $\mathrm{IgA}$ antibody in $65 \%$ of patients with ocular paratrachoma from whom the organism was isolated. ${ }^{74}$ Similar results were obtained from schoolchildren with trachoma in southern Tunisia. Tear antibodies were present in $75 \%$ of isolation positive patients but only in $20 \%$ of those which were isolation negative. Seventy percent of those with severe 
trachoma had tear antibodies compared to only $31 \%$ of those with moderate disease and $17 \%$ of those with mild disease. ${ }^{76}$

A combination of blood and tear serology can provide a valid provisional diagnosis in about $90 \%$ of patients with chlamydial ocular infections. ${ }^{61}$ Conversely, the absence of antibodies from serum and local discharges may indicate that chlamydiae are unlikely to be the pathogens involved in a particular infection.

Following on from experience with the microimmunofluorescence test for chlamydial antibodies, an indirect micro-immunofluorescence test has been developed for detecting typespecific antibodies to $\mathrm{HSV} .{ }^{77}$ This test used purified virus particles spotted onto a microscope slide in a similar manner to the chlamydial antibody test. Both HSV-1 and HSV-2 antigens were used and the test could differentiate antibodies to these two serotypes. In HSV-1 infections, the antibody titre against HSV-1 was four-fold or more higher than against HSV-2. However, in HSV-2 infections, the titres to both serotypes were equal or differed by up to twofold only. The test was also able to identify antiHSV IgG, IgM and IgA classes of antibody.

As with chlamydial antibodies, seroconversion or a four-fold rise in antibody titre can provide a definitive diagnosis for HSV ocular infections, but many patients have antibodies to HSV due to infections at other sites and many others may be experiencing recurrence of the disease. IgM antibodies may be found following the first infection with the virus but not during recurrences. In a study of HSV-isolation positive patients at Moorfields Eye Hospital, nine out of 29 patients $(31 \%)$ had no antibodies while the other 20 had $\operatorname{IgG}$ antibodies in blood. None had IgM antibodies either alone or with IgG antibodies against HSV-1. ${ }^{78}$ Serological studies of 28 patients with typical dendritic corneal ulceration showed that six patients $(21 \%)$ seroconverted, and were therefore presumably experiencing their first exposure, while another patient had a four-fold rise in blood $\mathrm{IgG}^{79}$

It has been suggested that secretory $\operatorname{IgA}$ in tears may be a good indicator of HSV ocular infection since it was found in significantly more patients with HSV eye infections than in control patients and was locally produced. In contrast, $\mathrm{IgG}$ and $\mathrm{IgA}$ antibodies were found in tears from patients with HSV eye infections and from other patients with inflamed eyes and were never present at higher levels than in sera and were probably transudated from the blood into tears in inflamed eyes. ${ }^{80,81}$

An immunofluorescence test for the serodiagnosis of herpes zoster ophthalmicus (HZO) has also been developed. ${ }^{82}$ The antigen used in this test was provided by varicella-zoster virusinfected cells grown on microscope slides. IgG antibodies at a titre of 1:256 or higher were detected in $80 \%$ of 134 sera from patients with a clinical diagnosis of $\mathrm{HZO}$, and IgM antibodies were present in six of them at a titre of $1: 8$. Only $1 \%$ of patients in a control group had similar IgG titres. Cross-reactions, with HSV antibodies were noticed but at such low titres that they did not interfere with the detection of antibodies to varicella-zoster virus.

\section{Future Developments}

The ideal diagnostic test has not yet been developed for ocular infections. No single test can be relied on to give a certain diagnosis in all cases. It is therefore necessary for the ophthalmologist to correlate the results of a diagnostic test together with the clinical picture to determine the cause of the disease and hence the correct method of treatment.

The presently available chlamydial direct detection tests are quick, easy to perform and can detect non-viable organisms. However, their sensitivity tends to be lower than isolation tests and there is a danger of false positive results. Since these tests detect killed and living organisms and antigens derived from the organisms, they are probably less suitable than culture tests for monitoring the effect of treatment, as antigens may persist after the organisms have been killed. The need in most cases to send specimens for these tests to specialist laboratories means that results are not available any quicker than with other tests. They may perform well in high risk populations but lack the specificity required for reliable use in low risk populations. ${ }^{83}$

Other types of direct detection test are being developed. For example, preliminary studies have indicated that DNA hybridisation may be used to detect chlamydiae in clinical material but the sensitivity of this method is rather low at present. ${ }^{84}$ There is clearly a need for tests which are simple and reliable enough to be 
performed in the clinic while the patient waits, and this must be the ultimate aim in the development of direct detection tests.

Culture tests typically take several days to perform and require viable organisms but the result is generally unequivocal. They therefore have a high specificity and are still widely regarded as the diagnostic method of choice for chlamydial infections. ${ }^{83}$ However, the sensitivity of culture tests depend on the quality of the specimens and the method of transportation and storage to preserve viability. It is likely that culture tests can be further improved to increase their sensitivity, reliability and speed, but there will inevitably be cases where they fail to give a positive result while other tests can detect dead organisms or extracellular antigens. This is, however, likely to be an advantage if these tests are used to monitor treatment of a disease.

Serological tests on a single specimen can in most cases only provide a provisional diagnosis or exclude a possible diagnosis, although the presence of certain types of antibodies in tear secretions correlate well with the clinical severity of disease. Further investigations of the most appropriate antigens to use and of the immunoglobulin types present during the disease may however lead to improvements in the diagnostic value of serological tests.

\section{References}

' Darougar S. Rapid diagnosis and management of ocular viral and chlamydial infections. Proceedings of the 1985 International Symposium on Medical Virology.

${ }^{2}$ Darougar S, Monnickendam MA, Woodland RM. Management and prevention of ocular viral and chlamydial infections. CRC Critical Reviews in Microbiology, (in press).

${ }^{3}$ Wishart PK, James C, Wishart MS, Darougar S. Prevalence of acute conjunctivitis caused by chlamydia, adenovirus, and herpes simplex virus in an ophthalmic casualty department. $\mathrm{Br} \mathrm{J}$ Ophthalmol 1984; 68: 653-5.

${ }^{4}$ Darougar S, Woodland RM, Walpita P. Value and cost effectiveness of double culture tests for diagnosis of ocular viral and chlamydial infections. Br J Ophthalmol 1987; 71: 673-5.

${ }^{5}$ Thygeson $\mathrm{P}$. The cytology of conjunctival exudates. Am J Ophthalmol 1946; 29: 1499-512.

${ }^{6}$ Yoneda C, Dawson CR, Dagfous T, Hoshiwara I, Jones P, Messadi M, Schachter J. Cytology as a guide to the presence of chlamydial inclusions in Giemsa-stained conjunctival smears in severe endemic trachoma. $\mathrm{Br} J$ Ophthalmol 1975; 59: 116-24.

${ }^{7}$ Thatcher RW, Darougar S, Jones BR. Conjunctival impression cytology. Arch Ophthalmol 1977; 95: 678-81.

${ }^{8}$ Halberstaedter L and von Prowazek S. Über zelleinschlüsse parasitärer natur beim trachom. Arb GesundhAmte 1907; 46: 44-7.

${ }^{9}$ Al-Hussaini KM, Jones BR, Dunlop EMC. Infection of the eye and genital tract by TRIC agent. I. Cytology and isolations. Rev Int Trachome 1965; 1: 7-13.

${ }^{10}$ Darougar S, Dwyer RStC, Treharne JD, Harper IA, Garland JA, Jones BR. A comparison of laboratory methods of diagnosis of chlamydial infection. In Nichols RL ed. Trachoma and related disorders caused by chlamydial agents. Amsterdam: Excerpt Medica 1971: 445-60.

${ }^{11}$ Darougar S, Woodland RM, Jones BR, Houshmand A, Farahmandian HA. Comparative sensitivity of fluorescent antibody staining of conjunctival scrapings and irradiated McCoy cell culture for the diagnosis of hyperendemic trachoma. $\mathrm{Br} \mathrm{J}$ Ophthalmol 1980; 64: 276-8.

${ }^{12}$ Woodland RM, El-Sheikh H, Darougar S, Squires S. Sensitivity of immunoperoxidase and immunofluorescence staining for detecting chlamydia in conjunctival scrapings and in cell culture. J Clin Pathol 1978; 31: 1073-7.

${ }^{13}$ Stephens RS, Tam MR, Kuo C-C, Nowinski RC. Monoclonal antibodies to Chlamydia trachomatis: Antibody specificities and antigen characterization. J Immunol 1982; 128: 1083-9.

${ }^{14}$ Tam MR, Stamm WE, Handsfield HH, Stephens $\mathrm{R}$, Kuo C-C, Holmes KK, Ditzenberger K, Krieger M, Nowinski RC. Culture-independent diagnosis of Chlamydia trachomatis using monoclonal antibodies. New Eng J Med 1984; 310: 1146-50.

15 Thomas BJ, Evans RT, Hawkins DA, TaylorRobinson D. Sensitivity of detecting Chlamydia trachomatis elementary bodies in smears by use of a fluoroscein labelled monoclonal antibody: comparison with conventional chlamydial isolation. J Clin Pathol 1984; 37: 812-6.

${ }^{16} \mathrm{~Eb} \mathrm{~F}$ and Orfila J. Rapid direct immunological procedures. Pro Eur Soc Chlamydia Res 1988; 1: 223-6.

${ }^{17}$ Bell TA, Kuo C-C, Stamm WE, Tam MR, Stephens RS, Holmes KK, Grayston JT. Direct fluorescent monoclonal antibody stain for rapid detection of infant Chlamydia trachomatis infections. Pediatrics 1984; 74: 224-8.

${ }^{18}$ Hawkins DA, Wilson RS, Thomas BJ, Evans RT. Rapid, reliable diagnosis of chlamydial opthalmia by means of monoclonal antibodies. $\mathrm{Br} J$ Ophthalmol 1985; 69: 640-4. 
${ }^{19}$ Mabey DC and Booth-Mason S. The detection of Chlamvdia trachomatis by direct immunofluorescence in conjunctival smears from patients with trachoma and patients with ophthalmia neonatorum using a conjugated monoclonal antibody. J Hygiene 1986: 96: 83-7.

${ }^{20}$ Lipkin ES, Moncada JV, Shafer M-A, Wilson TE, Schachter J. Comparison of monoclonal antibody staining and culture in diagnosing cervical chlamydial infection. J Clin Microbiol 1986; 23 : 114-7.

${ }^{21}$ Schwab IR, Raju VK, McClung J. Indirect immunofluorescent antibody diagnosis of herpes simplex with upper tarsal and corneal scrapings. Ophthalmol 1986; 93: 752-6.

22 Collum LMT, Mullaney J. Hillery M, Mullaney P, Lester R. Two laboratory methods for diagnosis of herpes simplex keratitis. $\mathrm{Br} J$ Ophthalmol 1987: 71: 742-5.

2.3 Botcherby M, Gilchrisı C, Bremner J, Byrne MA, Harris JR, Taylor-Robinson D. Rapid diagnosis of genital herpes by detecting cells infected with virus in smears with fluorescent monoclonal antibodies. J Clin Pathol 1987; 40: 687-9.

${ }^{24}$ Vastine DW, Schwartz AS, Yamashiroya HM, Smith RF, Guth SB. Cytologic diagnosis of adenoviral epidemic keratoconjunctivitis by direct immunofluorescence. Ophthalmol 1977; 16: $195-200$.

${ }^{25}$ Sherwood D. Evaluation of an immunofluorescence test and an amplified enzyme immunoassay for the direct detection of Chlamydia trachomatis in urino-genital specimens. In Oriel D, Ridgway G, Schachter J, Taylor-Robinson D, Ward M eds. Chlamydial infections. Cambridge: Cambridge University Press 1986: 554-7.

${ }^{26}$ Treharne JD, Viswalingam ND, Woodland RM, Yearsley PJ, Gooch JM. An improved amplified enyme immunoassay for the direct detection of Chlamydia trachomatis in ocular infections. Proc Eur Soc Chlamydia Res 1988, 1: 248.

27 Meurman O, Ruuskanen O, Sarkkinen H. Immunoassay diagnosis of adenovirus infections in children. J Clin Microbiol 1983; 18: 1190-5.

${ }^{28}$ Clayton AL, Roberts C, Godley M, Best JM, Chantler SM. Herpes simplex virus detection by ELISA: effect of enzyme amplification, nature of lesion sampled and specimen treatment. $J$ Med Virol 1986; 20: 89-97.

${ }^{29}$ T'ang F-F, Chang H-L, Huang Y-T, Wang K-C. Studies on the etiology of trachoma with special reference to isolation of the virus in chick embryo. Chin Med J 1957; 75: 429-47.

30 Collier LH and Sowa J. Isolation of trachoma virus in embryonate eggs. Lancet 1958; i: 993-6.
${ }^{31}$ Jones BR, Collier LH, Smith $\mathrm{CH}$. Isolation of virus from inclusion blennorrhoea. Lancet 1959; i: $902-5$.

${ }^{32}$ Harper IA, Dwyer RStC, Garland JA, Jones BR, Treharne JD, Dunlop EMC, Freedman A, Race JW. Infection by Bedsoniae and the possibility of spurious isolation: 1. Cross-infection of eggs during culture. Am J Ophthalmol 1967; 63: 1064-73,

${ }^{33}$ Larin NM and Treharne JD. Behaviour in eggs and tissue culture of the inclusion blennorrhoea (LB4) strain of the trachoma-inclusion conjunctivitis group. Nature 1964; 204: 166-7.

${ }^{34}$ Gordon FB. Magruder GB, Quan AL, Arm HG. Cell cultures for detection of trachoma virus from experimental simian infections. Proc Soc Exp Biol Med 1963; 112: 236-42.

${ }^{35}$ Gordon FB, Dressler HR, Quan AL. Relative sensitivity of cell culture and yolk sac for detection of TRIC infection. Am J Ophthalmol 1967; 63: 1044-8.

${ }^{36}$ Gordon FB, Harper IA, Quan AL, Treharne JD, Dwyer RStC, Garland JA. Detection of chlamydia (Bedsonia) in certain infections of Man. I. Laboratory procedures: comparison of yolk sac and cell culture for detection and isolation. J Infect Dis 1969; 120: 451-62.

${ }^{37}$ Darougar S, Kinnison JR, Jones BR. Simplified irradiated McCoy cell culture for isolation of chlamydiae. In Nichols RL ed. Trachoma and related disorders caused by chlamydial agents. Amsterdam: Excerpta Medica 1971: 63-70.

${ }^{38}$ Darougar S, Jones BR, Kinnison JR, VaughanJackson JD, Dunlop EMC. Chlamydial infection: Advances in the diagnostic isolation of Chlamydia, including TRIC agent, from the eye, genital tract, and rectum. Br J Vener Dis 1972; 48: 416-20.

${ }^{39}$ Darougar S and Jones BR. Conjunctival swabbing for the isolation of TRIC agent (Chlamydia). $\mathrm{Br}$ J Ophthalmol 1971; 55: 585-90.

${ }^{40}$ Darougar S, Cubitt S, Jones BR. Effect of highspeed centrifugation on the sensitivity of irradiated McCoy cell culture for the isolation of Chlamydia. Br J Vener Dis 1974; 50: 308-12.

${ }^{4}$ Evans RT and Woodland RM. Detection of chlamydiae by isolation and direct examination. Br Med Bull 1983; 39: 181-6.

${ }^{42}$ Woodland RM, Kirton RP, Darougar S. Sensitivity of mitomycin-C treated McCoy cells for isolation of Chlamydia trachomatis from genital specimens. Eur J Clin Microbiol 1987; 6: 653-6.

43 Woodland RM, Malam J, Darougar S. A rapid method for staining inclusions of Chlamydia psittaci and Chlamydia trachomatis. J Clin Pathol 1982; 35: 642-4. 
44 Thomas BJ, Evans RT, Hutchinson GR, TaylorRobinson D. Early detection of chlamydial inclusions combining the use of cycloheximidetreated McCoy cells and immunofluorescence staining. J Clin Microbiol 1977; 6: 285-92.

${ }^{45}$ McSwiggan DA, Darougar S. Rahman AFMS, Gibson JA. Comparison of the sensitivity of human embryo kidney cells, HeLa cells, and W138 cells for the primary isolation of viruses from the eye. J Clin Pathol 1975; 28 : 410-3.

${ }^{46}$ Gibson JA, Darougar S, McSwiggan DA. Thaker U. Comparative sensitivity of a cultural test and a complement fixation test in the diagnosis of adenovirus ocular infection. $\mathrm{Br} \mathrm{J}$ Ophthalmol 1979; 63: 617-20.

${ }^{47}$ Darougar S, Walpita P. Thaker U, Viswalingam N, Wishart MS. Rapid culture test for adenovirus isolation. $\mathrm{Br} J$ Ophthalmol 1984; 68: 405-8.

${ }^{48}$ Walpita P, Darougar S. Thaker U. A rapid and sensitive culture test for detecting herpes simplex virus from the eye. $\mathrm{Br} J$ Ophthalmol 1985; 69: 637-9.

${ }^{49}$ Darougar S, Gibson JA. Thaker U. Effect of centrifugation on herpes simplex virus isolation. J Med Virol 1981; 8: 231-5.

${ }^{50}$ Walpita, (paper in preparation).

${ }^{51}$ Schachter J and Dawson CR. Human chlamydial infections. Littleton, Mass. PSG Publishing Co. Inc., 1978.

${ }^{52}$ Barwell CF. Dunlop EMC, Race JW. Results of complement-fixation and intradermal tests for Bedsoniae in genital infection, disease of the eye and Reiter's disease. Am J Ophthalmol 1967; 63: 1527-34.

${ }^{53}$ Tarrizo ML, Nabli B, Labonne J. Studies on trachoma. II. Evaluation of laboratory diagnostic methods under field conditions. Bull WHO 1968: 38: 897-905.

54 Treharne JD. Chlamydia trachomatis: Serological diagnosis. Infection 1982; 10: Suppl. 1: S25-31.

55 Wang S-P and Grayston JT. Immunologic relationship between genital TRIC, lymphogranuloma venereum, and related organisms in a new microtiter indirect immunofluorescence test. $\mathrm{Am}$ J Ophthalmol 1970; 70: 367-74.

${ }^{56}$ Wang S-P and Grayston JT. Classification of TRIC and related strains with microimmunofluorescence. In Nichols RL ed. Trachoma and related disorders caused by chlamydial agents. Amsterdam: Excerpta Medica 1971: 305-21.

57 Wang S-P, Grayston JT, Gale JL. Three new immunologic types of trachoma-inclusion conjunctivitis organisms. J Immunol 1973; 110: 873-9.

58 Treharne JD, Darougar S, Jones BR. Characterization of a further microimmunofluorescence serotype of Chlamydia: TRIC Type G. Br J Vener Dis 1973; 49: 295-300.
59 Jones BR. Prevention of blindness from trachoma. Trans Ophthalmol Soc UK 1975; 95: 16-33.

${ }^{60}$ Dwyer RStC, Treharne JD, Jones BR, Herring J. Chlamydial infection: Results of microimmunofluorescence tests for the detection of typespecific antibody in certain chlamydial infections. Br J Vener Dis 1972; 48: 452-9.

${ }^{61}$ Darougar S, Treharne JD, Minassian. D, El-Sheikh H, Dines RJ, Jones BR. Rapid serological test for diagnosis of chlamydial ocular infections. $\mathrm{Br} J$ Ophthalmoi 1978; 62: 503-8.

62 Treharne JD, Darougar S, Jones BR. Modification of the microimmunofluorescence test to provide a routine serodiagnostic test for chlamydial infection. J Clin Pathol 1977; 30: 510-7.

${ }^{63}$ Thomas BJ, Reeve P, Oriel JD. Simplified serological test for antibodies to Chlamydia trachomatis. J Clin Microbiol 1976; 4: 6-10.

${ }^{64}$ Richmond SJ and Caul EO. Single-antigen indirect immunofluorescence test for screening venereal disease clinic populations for chlamydial antibodies. In Hobson D and Holmes KK eds. Nongonococcal urethritis and related infections. Washington DC: America Society for Microbiology 1977: 259-65.

${ }^{65}$ Saikku $P$ and Paavonen P. Single-antigen immunofluorescence test for chlamydial antibodies. J Clin Microbiol 1978; 8: 119-22.

66 Terho $P$ and Meurman O. Chlamydial serum IgG, IgA and local IgA antibodies in patients with genital tract infections measured by solid-phase radioimmunoassay. J Med Microbiol 1981; 14: 77-87.

${ }^{67}$ Levy JN and McCormack WM. Detection of serum antibody to Chlamydia with ELISA. In Mardh P-A, Holmes KK, Oriel JD, Piot P, Schachter J eds. Chlamydial infections, Amsterdam: Elsevier Biomedical Press 1982: 341-4.

${ }^{68}$ Evans RT and Taylor-Robinson D. Development and evaluation of an enzyme-linked immunosorbent assay (ELISA) using chlamydial group antigen, to detect antibodies to Chlamydia trachomatis. J Clin Pathol 1982; 35: 1122-8.

${ }^{69}$ Kuo CC, Chen HH, Wang SP, Grayston JT. Characterisation of TWAR strains, a new group of Chlamydia psittaci. In Oriel D, Ridgway G, Schachter J, Taylor-Robinson D, Ward $\mathbf{M}$ eds. Chlamydial infections. Cambridge: Cambridge University Press 1986; 321-4.

${ }^{70}$ Wang SP and Grayston JT. Microimmunofluorescence serological studies with the TWAR organism. In Oriel D, Ridgway G, Schachter J, Taylor-Robinson D, Ward $\mathbf{M}$ eds. Chlamydial infections. Cambridge: Cambridge University Press 1986: 329-32.

${ }^{71}$ Darougar S, Forsey T, Brewerton DA, Rogers KL. Prevalence of antichlamydial antibody in London blood donors. Br J Vener Dis 1980; 56: 404-7. 
${ }^{72}$ Forsey T, Darougar S, Treharne JD. Prevalence in human being of antibodies to Chlamydia IOL-207, an atypical strain of chlamydia. $J$ Infect 1986; 12: 145-52.

${ }^{73}$ Forsey T, Stainsby K, Hoger PH, Ridgway GL, Darougar S, Fischer-Brugge U. Comparison of two immunofluorescence tests for detecting antibodies to $C$. trachomatis. Eur J Epidemiol 1986; 2: 163-4.

${ }^{74}$ Treharne JD, Forsey T, Thomas BJ. Chlamydial serology. Br Med Bull 1983; 39: 194-200.

${ }^{75}$ Sarov I, Sarov B, Lunefeld E, Zion H, Chaim W, Piura B. The significance of chlamydia specific serum IgA antibodies in Chlamydia trachomatis infections. Proc Eur Soc Chlamydia Res 1988; 1: 234-8.

${ }^{76}$ Treharne JD, Dwyer RStC, Darougar S, Jones BR, Daghfous T. Antichlamydial antibody in tears and sera, and serotypes of Chlamydia trachomatis isolated from schoolchildren in southern Tunisia. Br J Ophthalmol 1978; 62: 509-15.

${ }^{77}$ Forsey $\mathrm{T}$ and Darougar $\mathrm{S}$. Indirect microimmunofluorescence test for detecting typespecific antibodies to herpes simplex virus. $J$ Clin Pathol 1980; 33: 171-6.

${ }^{78}$ Darougar S, (personal communication).

${ }^{79}$ Wilhelmus KR, Darougar S, Forsey T, Treharne JD. Sequential antibody changes following ulcerative herpetic keratitis. $\mathrm{Br} \mathrm{J}$ Ophthalmol 1986; 70: 354-6.

${ }^{80}$ Pedersen B, Møller Anderson S, Klauber A, Ottovay E, Prause JU, Chen Z, Norrild B. Secretory IgA specific for herpes simplex virus in lacrimal fluid from patients with herpes keratitis - a possible diagnostic parameter. $\mathrm{Br} J$ Ophthalmol 1982; 66: 648-53.

${ }^{81}$ Fox PD, Khaw PT, McBride BW, McGill JI, Ward KA. Tear and serum antibody levels in ocular herpetic infections diagnostic precision of secretory IgA. Br J Ophthalmol 1986; 70: 584-8.

82 Walpita P, Darougar S, Marsh RJ, Cooper M. Development of an immunofluorescence test for the serodiagnosis of herpes zoster ophthalmicus. Br J Ophthalmol 1986; 70: 431-4.
${ }^{83}$ Ridgway GL. The laboratory diagnosis of chlamydial infection. In Oriel D, Ridgway G, Schachter J, Taylor-Robinson D, Ward M eds. Chlamydial infections. Cambridge: Cambridge University Press 1986: 539-49.

${ }^{84}$ Hypiä T, Jalava A, Larsen SH, Terho P, Hukkanen V. Detection of Chlamydia trachomatis in clinical specimens by nucleic acid spot hydridization. $J$ Gen Microbiol 1985; 131: 1-4.

${ }^{85}$ Kuo C-C, Wang S-P, Wentworth BB, Grayston JT. Primary isolation of TRIC organisms in HeLa 229 cells treated with DEAE-dextran. $J$ Infect Dis 1972, 125: 665-8.

${ }^{86}$ Darougar S, Kundu D, Jones BR. Comparison of the sensitivity of primary isolation of Chlamydia in irradiated McCoy cells or HeLa 229 cells treated with diethylaminoethyldextran (DEAED). Br J Ophthalmol 1974; 58: 843-9.

${ }^{87}$ Wentworth BB and Alexander ER. Isolation of Chlamydia trachomatis by use of 5-iodo-2-deoxyuridine treated cells. Appl Microbiol 1974; 27: 912-6.

${ }^{88}$ Sompolinsky D and Richmond S. Growth of Chlamydia trachomatis in McCoy cells treated with cytochalasin B. Appl Microbiol 1974; 28: 912-4.

${ }^{89}$ Blythe WA and Taverne J. Cultivation of TRIC agents: a comparison between the use of BHK-21 and irradiated McCoy cells. J Hyg 1974; 72 : 121-8.

${ }^{90}$ Ripa KV and Mardh PA. New simplified culture technique for Chlamydia trachomatis. In Hobson $\mathrm{D}$ and Holmes KK eds. Nongonococcal urethritis and related infections. Washington DC: American Society for Microbiology 1977: 323-7.

${ }^{91}$ Bushell AC and Hobson D. Effect of cortisol on the growth of Chlamydia trachomatis in McCoy cells. Infect Immun 1978; 21: 946-53.

${ }^{92}$ Paul ID. The growth of Chlamydia in McCoy cells treated with emetine. Med Lab Sci 1982; 39: 15-32.

${ }^{93}$ Hobson D, Lee N, Quayle E, Beckett EE. Growth of Chlamydia trachomatis in Buffalo Green Monkey Cells. Lancet 1982; ii: 872-3. 